\title{
Bekas Benteng-Benteng Belanda Di Jawa: Penggunaan Dan "Penyalahgunaannya"
}

\section{Novida Abbas}

Keywords: cultural resource management, fort, fortresses, dutch, conservation, protection, utilization

\section{How to Cite:}

Abbas, N. (2002). Bekas Benteng-Benteng Belanda Di Jawa: Penggunaan Dan "Penyalahgunaannya". Berkala Arkeologi, 22(1), 96-105. https://doi.org/10.30883/jba.v22i1.853

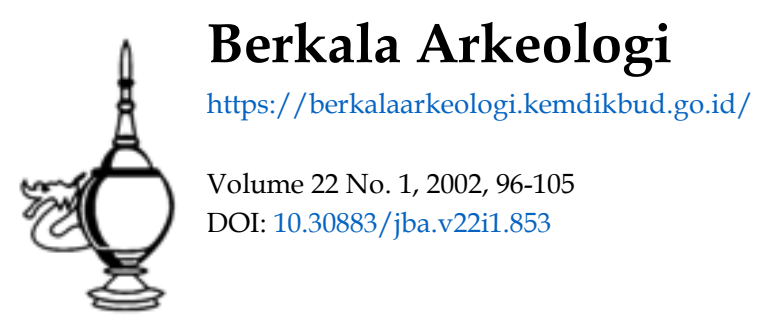

\section{(c) (1)(2)(2)}

This work is licensed under a Creative Commons Attribution-NonCommercial-ShareAlike 4.0 International License. 


\title{
BEKAS BENTENG-BENTENG BELANDA DI JAWA: PENGGUNAAN DAN "PENYALAHGUNAANNYA"
}

\author{
Novida Abbas \\ (Balai Arkeologi Yogyakarta)
}

\section{Pendahuluan}

Benteng, sebagai salah satu tinggalan arkeologi militer yang mendapat pengaruh Eropa, cukup banyak dibangun di Jawa selama masa pendudukan Belanda. Jumlah benteng yang pernah dibangun oleh Belanda di Jawa bahkan melebihi jumlah benteng yang mereka bangun di Maluku, yang sebenarnya merupakan tujuan utama mereka ketika pertama kali datang ke Nusantara.' Di Jawa sendiri, terdapat 34 bekas benteng Belanda. ${ }^{2}$ Dari jumlah tersebut, yang masih bisa disaksikan data fisiknya hingga kini berjumlah 15 buah, baik yang masih relatif utuh hingga berupa reruntuhan, tersebar dari barat hingga timur Pulau Jawa, termasuk di Nusa Kambangan dan Madura.

Dari sejumlah benteng yang tersisa tersebut, beberapa di antaranya hingga saat ini masih digunakan maupun akan digunakan dengan fungsinya yang baru. Dalam tulisan ini akan dikemukakan mengenai keberadaan sejumlah benteng Belanda yang masih eksis di Jawa dan masalah yang dihadapi benteng-benteng tersebut akibat penggunaan atau "penyalahgunaan" terhadap mereka.

\section{Penggunaan Bekas Benteng-benteng Belanda}

Penggunaan (termasuk rencana penggunaan) terhadap bekas benteng-benteng Belanda/kolonial yang masih eksis cukup beragam. ${ }^{3}$ Sebagai objek militer di masa lalu, hingga kini penggunaan ulang terbesar dari benteng-benteng tersebut adalah sebagai fasilitas militer, misalnya tangsi, asrama, rumah tahanan, maupun lembaga pemasyarakatan $(40 \%)$. Selanjutnya bekas benteng-benteng tersebut ada pula yang digunakan sebagai museum maupun objek wisata budaya (20\%), dan sisanya (40\%) terbagi antara yang tidak digunakan atau diabaikan (25.7\%), sebagai holding ground Dinas Peternakan, dan akan digunakan sebagai hotel.

1 Belum terdapat data inventarisasi resmi dari instansi yang berwenang/terkait mengenai jumlah benteng kolonial yang pernah "hadir" di berbagai pulau di Indonesia. Lihat Tabel 1 .

2 Tidak termasuk benteng lapangan/kubu pertahanan (redoubt) yang didirikan Belanda dalam menghadapi Perang Diponegoro, yaitu yang dikenal dengan benteng stelsel atau sistem benteng. Lihat Tabel 2.

3 Tabel 3. 
Segala bentuk penggunaan ulang bangunan kuna tersebut tentunya memiliki dampak sendiri-sendiri, yang sangat erat kaitannya dengan perubahan dari fungsi lama ke fungsi baru. Perubahan fungsi inilah yang terutama mempengaruhi fisik bangunan, yaitu diubah untuk disesuaikan dengan fungsi barunya. Dalam hal benteng, baik penggunaan ulangnya untuk kepentingan militer maupun non-militer secara umum dapat dikatakan menimbulkan berbagai perubahan, baik penambahan maupun pengurangan terhadap fisik bangunannya. Menyangkut sejumlah benteng yang masih tetap digunakan oleh militer, tampak bahwa fungsi bangunan tersebut sudah diubah. Dapat disebutkan beberapa contoh perubahan sebagai berikut:

Benteng Pekalongan yang dijadikan Rumah Tahanan Negara Pekalongan:

- Bastion diubah menjadi menara penjagaan: dari 4 bastion, 3 di antaranya telah diubah menjadi menara penjagaan, 1 sisanya masih tersisa bagian bawahnya, sementara bagian atas juga diubah untuk menara penjagaan.

- Perubahan bentuk pintu gerbang.

- Sebagian besar bangunan di bagian dalam diubah menjadi sel-sel tahanan.

Benteng Willem I di Ambarawa yang dijadikan Instalasi Tuna Tertib Militer:

- Sebagian ruang di lantai 1 dan 2 benteng dijadikan sel tahanan.

- Sebagian besar ruang lainnya dibiarkan terbengkalai.

- Pintu-pintu maupun jendela-jendela pads gudang amunisi dan menara penjagaan ditutup semen dan dibuat lubang-lubang kecil karena difungsikan sebagai tempat memelihara burung walet.

Benteng Van den Bosch di Ngawi yang dijadikan asrama Batalyon Artileri Medan:

- Bangunan-bangunan di bagian dalam benteng diubah untuk keperluan penghunian.

- Beberapa bagian tembok keliling, bastion, maupun pintu gerbang berada dalam keadaan rusak karena tidak terawat.

Sementara itu penggunaan ulang yang lain pada sejumlah benteng adalah sebagai objek wisata. Beberapa benteng yang sudah dimanfaatkan untuk itu adalah: Benteng Pendem di Cilacap, dan Benteng Cochius di Gombong. Benteng Pendem Cilacap telah dimanfaatkan sejak tahun 1987, sementara benteng Cochius di Gombong dimanfaatkan sejak tahun 2000. Sebelum difungsikan sebagai objek wisata, sebenarnya Benteng Pendem telah kehilangan sebagian besar areal bangunannya, yang digunakan oleh Pertamina sebagai tempat penyimpanan (tanki) minyak. Dengan fungsí barunya sebagai objek wisata, Benteng Pendem mengalami cukup banyak perubahan, antara lain:

- pembuatan gapura baru di halaman depan untuk loket penjualan tiket.

- pembuatan WC umum, musholla, dan jembatan di atas parit keliling benteng.

- pembuatan ayunan dan bangku beton di halaman dalam benteng. 
- pembuatan gardu pandang di bagian dalam benteng.

Selanjutnya Benteng Cochius baru difungsikan sebagai objek wisata pada tahun 2000 setelah direvitalisasi oleh $\mathrm{CV}$ Indo Power. Perubahan atau modifikasi yang terjadi pada Benteng Cochius antara lain:

- perubahan bagian atap untuk pembuatan rel kereta wisata/permainan.

- pembuatan stasiun kereta wisata/permainan di bagian tengah atap benteng.

- pembuatan air mancur di halaman dalam benteng.

- pembuatan kolam renang dan sarana bermain tepat di samping tenggara benteng.

- pembuatan patung-patung yang tidak selaras dengan 'suasana' benteng itu sendiri, seperti berbagai patung dinosaurus.

Sementara benteng-benteng yang tidak digunakan lagi juga mengalami masalah yang cukup memprihatinkan, terutama karena faktor alam. Sebagai contoh, benteng Jepara berada dalam kondisi cukup parah, karena sebagian tembok dan bastion telah runtuh. Demikian pula benteng Panarukan, yang tembok bentengnya hanya tersisa sebagian kecil saja, dan karena tidak digunakan lagi maka areal bagian dalam benteng dimanfaatkan untuk kompleks makam penduduk setempat. Benteng Karangbolong di Nusakambangan hampir seluruh permukaan bangunannya ditumbuhi pohon-pohon besar. Selain itu bagian dalam benteng juga mengalami kerusakan akibat tumbuhtumbuhan maupun ulah manusia.

Dari pemaparan di atas tampak bahwa berbagai jenis penggunaan (atau "penyalahgunaan"?) terhadap benteng-benteng kolonial tersebut mengakibatkan berubahnya fisik bangunan, baik sedikit, banyak, maupun hampir total.

\section{Pembahasan}

Tinggalan arkeologi militer adalah bagian yang penting dari sumberdaya arkeologi, karena mereka merupakan refleksi dari berbagai peristiwa sejarah yang membentuk suatu bangsa dan mengantarkan bangsa sampai pada keadaannya di masa kini. Berbagai argumentasi dalam mengupayakan pelestarian tinggalan arkeologi militer di berbagai negara antara lain menghasilkan sejumlah pandangan sebagai berikut:

- untuk menjaga dan memupuk rasa kesejarahan suatu bangsa.

- untuk memberi ciri pada kota-kota atau wilayah-wilayah sekaligus menumbuhkan rasa memiliki terhadap tempat dan komunitas yang memiliki peran penting pada masa perang.

- peran penting dalam sejarah bangsa, misalnya perubahan karakter dalam sistem pertahanan, yang dapat dilihat dari konteks fisik dan strategi. 
- bersama dengan sumber-sumber sejarah lainnya memberi peluang bagi para arkeolog maupun para (calon) pengelola untuk mengubah sesuatu yang 'mati' menjadi pernyataan pengalaman yang hidup, yang penting bagi pendidikan maupun wawasan kebangsaan.

- nilai penting ekonomi.

Kembali kepada berbagai kasus yang terjadi terhadap sejumlah bekas benteng Belanda di Jawa, tampaknya upaya pelestarian terhadap bekas benteng-benteng tersebut belum sepenuhnya dilakukan. Jumlah bangunan kolonial seperti, misalnya, rumah tinggal, gedung-gedung perkantoran, dan gereja, yang sudah dilestarikan sejauh ini sudah cukup banyak, tetapi tidak demikian hanya dengan tinggalan berupa benteng, padahal ditilik dari segi kuantitas, jumlah benteng cukup langka jika dibandingkan dengan jenis bangunan kolonial lainnya. Perhatian terhadap benteng kolonial (dalam hal ini perhatian untuk melestarikannya) jelas masih sangat kurang. Bangunan-bangunan kolonial yang telah dilestarikan terutama yang dianggap memiliki nilai historis tinggi, nilai arsitektural tinggi, maupun yang dianggap berperan dalam membentuk wajah suatu kota (seperti misalnya, kawasan perumahan di Candi, Semarang; Kotabaru di Yogya). Kenyataan tersebut di atas mungkin disebabkan karena selama ini belum terpikirkan apa yang akan atau harus dilakukan terhadap benteng-benteng tersebut seandainya ingin dilestarikan, sebab terdapat sejumlah faktor yang dapat dipandang sebagai hambatan jika benteng-benteng itu akan dilestarikan. Sebagai contoh, karena faktor keletakannya yang umumnya di daerah terpencil maka urgensinya kurang tinggi untuk dilestarikan, fungsi setelah dilestarikan, dan faktor kepemilikan yang sebagian besar masih berada di tangan militer.

\section{Apa Yang Harus Dilakukan Terhadap Benteng?}

Belajar dari berbagai kenyctaan yang dijumpai di lapangan, tampaknya perlu untuk meluruskan berbagai hal maupun pandangan yang menyebabkan terabaikannya pelestarian tinggalan-tinggalan arkeologis, dalam hal ini khususnya benteng. Pertanyaan yang muncul adalah apa yang harus dilakukan terhadap benteng? Apabila benteng dianggap perlu untık dilestarikan, maka diperlukan perangkat pengelola dan pengelolaan yang dapat mındiri setelah suatu jangka waktu tertentu. Persoalannya sekarang adalah: a. bagaiınana mengelola benteng untuk melestarikannya? dan b. bagaimana membangkitkan pendanaan untuk upaya pengelolaan/pelestarian?

Hal yang paling mendasar adalah rencana pengelolaan yang komprehensif sampai pada alternatif pemanfaatannya, sebab telah banyak terjadi pemanfaatan atau penggunaan ulang suatu tinggalan (dalam hal ini tinggalan bercorak kolonial) ternyata pada akhirnya tidak seperti yang diharapkan. Sebagai contoh, penggunaan ulang 
bangunan kolonial sebagai museum yang ternyata tidak banyak dikunjungi, sehingga berakibat pada kurangnya dana untuk pemeliharaan bangunan itu sendiri dan berujung pada tidak terawatnya bangunan tersebut yang menjurus pada kerusakan bangunan, sehingga tujuan pelestarian-pemanfaatannya tidak tercapai. Selain itu, untuk melengkapi rencana pengelolaan tersebut harus disertakan rencana pendanaan yang laik. Melihat beberapa kasus yang terjadi pada benteng-benteng Belanda di Jawa, jelas sekali pemanfaatan yang terjadi di situ bukan pemanfaatan yang berwawasan pelestarian, yang salah satu prasyaratnya adalah sejauh mungkin terlestarikannya kondisi fisik tinggalan dan bila dimanfaatkan untuk kegunaan lain, sedapat mungkin tidak mengubah bentuk fisik.

Dalam kasus berbagai benteng di Jawa prinsip dasar pelestarian jelas terabaikan. Hal ini dapat disebabkan karena ketidaktahuan pengelola benteng dan atau tidak adanya rencana pengelolaan. Meskipun di satu sisi pemanfaatannya menghasilkan dana (seperti di Benteng Pendem dan Benteng Cochius), tetapi aspek pelestariannya sendiri terbengkalai.

\section{Penutup}

Tinggalan arkeologis berupa benteng menjadi salah satu permasalahan dalam manajemen sumberdaya budaya. Di satu sisi, terlihat bahwa benteng-benteng tersebut perlu mendapat perhatian dan perlu dilestarikan, tetapi di sisi lain berbagai faktor tampak kurang menunjang upaya ke arah pelestarian tersebut. Diharapkan dengan maraknya minat terhadap pelestarian berbagai warisan budaya, tinggalan berupa benteng pun dapat "tersentuh" oleh upaya tersebut, sebelum yang tertinggal benarbenar hanya sepenggal kisah. 


\section{KEPUSTAKAAN}

Abbas, Novida. 2001. Dutch Forts of Java : A Locational Study. Tesis. National University of Singapore.

Abbas, Novida \& Ratna Suranti. 1997. Beberapa Benteng Belanda di Jawa Tengah: Kajian Formal dan Permasalahan Pelestarian-Pemanfaatannya, dalam Cinandi. Yogyakarta: Panitia Lustrum VII Jurusan Arkeologi FS-UGM, pp. $1-17$.

Australian Heritage Commission. 2000. Protecting Local Heritage Places. Canberra.

Carman, J. 1997. Approaches to Violence, dalam J. Carman (ed.), Material Harm: Archaeological Studies of War and Violence. Glasgow: Cruithne Press, pp. $1-23$.

Haryadi (ed.). 1998/1999. Laporan Studi Kelayakan Benteng Pendem Cilacap. Bagian Proyek Pembinaan Peninggalan Sejarah dan Kepurbakalaan Jawa Tengah.

Planel, P. 1995. A Teacher's Guide to Battlefields, Defence, Conflict and Warfare. London: English Heritage.

Schofield, J. 1999. Conserving Recent Military Remains, dalam Gill Chitty \& David Baker (eds.), Managing Historic Sites and Buildings. London: Routledge, pp. 173-186. 
Tabel 1 BENTENG BELANDA DI INDONESIA (SELAIN JAWA)*

\begin{tabular}{|c|c|c|c|c|}
\hline No. & Pulau/Kepulauan & Benteng & $\begin{array}{c}\text { Thn } \\
\text { pendirian }\end{array}$ & Lokasi \\
\hline I & Maluku & & & \\
\hline 01. & & Van Verre & 1600 & Ambon \\
\hline 02. & & Victoria & 1605 & Ambon \\
\hline 03. & & Oranje & 1607 & Ternate \\
\hline 04. & & Vlissingen & 1608 & Nusa Ela, Ambon \\
\hline 05. & & Nassau & 1609 & Neira \\
\hline 06. & & Kalamatta & 1609 & Kayu Merah \\
\hline 07. & & Barneveld & 1609 & Bacan \\
\hline 08. & & Willemstad & 1609 & Takomi, Ternate \\
\hline 09. & & Belgica & 1611 & Neira \\
\hline 10. & & Mauritius & 1612 & Makian \\
\hline 11. & & Revengie & 1616 & $\mathrm{Ai}$ \\
\hline 12. & & Hollandia & 1621 & Saparua \\
\hline 13. & & Nieuw-Zeelandia & 1626 & Haruku, Saparua \\
\hline 14. & & De Zeven Provinciën & 1600 & Tafasoho \\
\hline 15. & & Concordia & 1630 & Lontor \\
\hline 16. & & Rotterdam & 1633 & Larike, Ambon \\
\hline 17. & & Amsterdam & 1642 & Hila, Ambon \\
\hline 18. & & Hardenberg & 1646 & Seram Kecil \\
\hline 19. & & Overburg & 1647 & Luhu, Seram \\
\hline 20. & & De Verwachting & 1650 & Sanana, Ternate \\
\hline 21. & & Hoorn & 1656 & Pilauw, Saparua \\
\hline 22. & & Leiden & 1656 & Hitu, Ambon \\
\hline 23. & & Wantrouw & 1657 & Manipa \\
\hline 24. & & Defensie & 1657 & Kayeli, Buru \\
\hline 25. & & Duurstede $\mathbf{E}$ & 1692 & Saparua \\
\hline II & Sulawesi & & & \\
\hline 01. & & Nieuwe-Amsterdam & 1657 & Manado \\
\hline 02. & & Rotterdam & 1667 & Makassar \\
\hline 03. & & Amurang & 1700 & Amurang \\
\hline 04. & & Nassau & 1756 & Gorontalo \\
\hline 05. & & Leiden & 1766 & Kwandang \\
\hline 06. & & Balangnipa & 1864 & Balangnipa \\
\hline 07. & & Kota Mas & $(?)$ & Kwandang \\
\hline 08. & & Purmerland & $(?)$ & Samboppo \\
\hline
\end{tabular}




\begin{tabular}{|c|l|l|c|l|}
\hline No. & Pulau/Kepulauan & \multicolumn{1}{|c|}{ Benteng } & $\begin{array}{c}\text { Thn } \\
\text { pendirian }\end{array}$ & \multicolumn{1}{|c|}{ Lokasi } \\
\hline 09. & & Victoria & $(?)$ & Tossora \\
\hline 10. & & Pangkajene & $(?)$ & Pangkajene \\
\hline 11. & & Segeri & $(?)$ & Segeri \\
\hline 12. & & Lebakkang & $(?)$ & Lebakang \\
\hline 13. & & Vosmaer & $(?)$ & Kendari \\
\hline & & & & \\
\hline III & Kalimantan & & & \\
\hline 01. & & Sukadana & 1606 & Sukadana \\
\hline 02. & & Landak & 1608 & Landak \\
\hline 03. & & Martapura & 1683 & Martapura \\
\hline 04. & & Tatas & 1756 & Banjarmasin \\
\hline 05. & & Puntiano & 1779 & Pontianak \\
\hline 06. & & Tabanio & 1789 & Tabanio \\
\hline & & & & \\
\hline IV & Sumatra & & & \\
\hline 01. & & Guntung & 1761 & Siak \\
\hline 02. & & Padang & 1781 & Padang \\
\hline 03. & & Van der Capellen & 1822 & Batusangkar \\
\hline 04. & & De Kock & 1825 & Bukittinggi \\
\hline V & Timor & & & \\
\hline 01. & & Concordia & 1611 & Kupang \\
\hline 02. & & Atapupu & $(?)$ & Atapupu \\
\hline & & & & \\
\hline VI & Papua & Du Bus & 1828 & Lobo \\
\hline 01. & & & & \\
\hline & & & & \\
\hline
\end{tabular}

* Sumber: Encyclopaedie van Nederlandsch Indië, 1ste, 3de \& 4de deel, 1917, 1919 \& 1921; O.V. 1929: 102-117; Wall, 1922-1923: 317-320; Wall, 1928; Wall, 1930: 83-128; Wall, 1930-1931: 293-305.

Telah ditetapkan sebagai BCB 
Tabel 2 BENTENG BELANDA DI JAWA

\begin{tabular}{|c|c|c|c|}
\hline No. & Benteng & Lokasi & Periode \\
\hline 01. & Batavia & Jakarta & Awal abad XVII \\
\hline 02. & Jepara & Jepara & Akhir abad XVII \\
\hline 03. & Tanjung Pura & Krawang & Akhir abad XVII \\
\hline 04. & Beschermer & Cirebon & Akhir abad XVII \\
\hline 05. & Tegal & Tegal & Akhir abad XVII \\
\hline 06. & Pekalongan & Pekalongan & Akhir abad XVII \\
\hline 07. & Goed Begin & Demak & Akhir abad XVII \\
\hline 08. & Juana & Juana & Akhir abad XVII \\
\hline 09. & Rembang & Rembang & Akhir abad XVII \\
\hline 10. & Kartasura & Kartasura & Akhir abad XVII \\
\hline 11. & Speelwijk & Banten & Akhir abad XVII \\
\hline 12. & Prins Oranje & Semarang & Awal abad XVIII \\
\hline 13. & De Bewaarder & Pasuruan & Awal abad XVIII \\
\hline 14. & Gresik & Gresik & Awal abad XVIII \\
\hline 15. & Bangkalan & Bangkalan & Pertengahan abad XVIII \\
\hline 16. & Willem II & Ungaran & Pertengahan abad XVIII \\
\hline 17. & Herstelling & Salatiga & Pertengahan abad XVIII \\
\hline 18. & Veldwachter & Boyolali & Pertengahan abad XVIII \\
\hline 19. & Utrecht & Banyuwangi & Pertengahan abad XVIII \\
\hline 20. & Engelenburg & Klaten & Akhir abad XVIII \\
\hline 21. & Vredeburg & Yogyakarta & Akhir abad XVIII \\
\hline 22. & Vastenburg & Surakarta & Akhir abad XVIII \\
\hline 23. & Panarukan & Panarukan & Akhir abad XVIII \\
\hline 24. & Besuki & Besuki & Akhir abad XVIII \\
\hline 25. & Probolinggo & Probolinggo & Akhir abad XVIII \\
\hline 26. & Sumenep & Sumenep & Akhir abad XVIII \\
\hline 27. & Kalimas & Surabaya & Awal abad XIX \\
\hline 28. & Lodewijk & Gresik & Awal abad XIX \\
\hline 29. & Willem I & Ambarawa & Awal abad XIX \\
\hline 30. & Prins Hendrik & Surabaya & Awal abad XIX \\
\hline 31. & Van den Bosch & Ngawi & Awal abad XIX \\
\hline 32. & Cochius & Gombong & Awal abad XIX \\
\hline 33. & Cilacap & Cilacap & Akhir abad XIX \\
\hline 34. & Karangbolong & Nusakambangan & Akhir abad XIX \\
\hline
\end{tabular}


Tabel 3 BENTENG BELANDA DI JAWA YANG MASIH EKSIS

\begin{tabular}{|l|l|l|}
\hline No. & \multicolumn{1}{|c|}{ Benteng \& Lokasi } & \multicolumn{1}{c|}{ Penggunaan saat ini } \\
\hline 01. & Jepara & Tidak digunakan \\
\hline 02. & Tegal & Lembaga Pemasyarakatan \\
\hline 03. & Pekalongan & Rumah Tahanan \\
\hline 04. & Speelwijk, Banten & Tidak digunakan \\
\hline 05. & Bangkalan & Asrama polisi \\
\hline 06. & Willem II, Ungaran & Asrama polisi \\
\hline 07. & Vredeburg, Yogyakarta $\}$ & Museum \\
\hline 08. & Vastenburg, Surakarta & Akan dijadikan hotel \\
\hline 09. & Panarukan & Pemakaman penduduk \\
\hline 10. & Sumenep & Holding ground Dinas Peternakan \\
\hline 11. & Willem I, Ambarawa & Rumah Tahanan Militer \\
\hline 12. & Van den Bosch, Ngawi & Asrama tentara \\
\hline 13. & Cochius, Gombong & Objek wisata \\
\hline 14. & Pendem, Cilacap & Objek wisata \\
\hline 15. & Karangbolong, Nusakambangan & Tidak digunakan \\
\hline
\end{tabular}

\} Sudah ditetapkan sebagai BCB 